\title{
Effect of Different Solutions on Seed Germination and Physiological Changes in Cicer arietinum
}

\author{
Sneha Pandey ${ }^{1}$, Kalpa Oza ${ }^{2 *}$, Bharat Maitreya ${ }^{3}$ \\ ${ }^{2} \mathrm{Ph} . \mathrm{D}$. Research Scholar, ${ }^{3}$ Professor of Botany Department \\ 1,2,3 Department of Botany, Bioinformatics, Climate change impact management, Gujarat University, School of
} Sciences, Ahmedabad, Gujarat, India

\section{Article Info \\ Volume 8, Issue 2 \\ Page Number : 295-300}

\section{Publication Issue}

March-April-2021

\section{Article History}

Accepted : 01 April 2021

Published : 03 April 2021

\section{ABSTRACT}

The chickpea is rich source of vitamins, fibers and minerals; it provides variety of health benefits like aiding weight management, improving digestion and lessens the risk of several diseases. The chickpea is high in protein and it is the best way to replace meat in vegetarian and vegan diets. For seed germination of chick pea generally used growth hormones like gibberellic acid (GA), IAA, IBA, salicylic acid and etc, PEG (polyethylene glycol) and control is used for comparison. In present work, the seeds of chickpea (Cicer arietinum) are treated with hormones like gibberellic acid salicylic acid solutions, PEG solution and as stress there is salt stress $(\mathrm{NaCl})$ and citric acid (CA) solutions to see the seeds germination under this circumstances, and seeds also germinated in control (distilled water) condition for comparison in petridish on whatman paper for 10 days after that the germinated seeds (PEG, gibberellic acid and distilled water) transferred to the mud pot with the soil and irrigate with their respective solutions for 20 days and take measurement and weight of plants after every 5 days interval.

Keywords : Vitamins, Fibers, Minerals, Hormones, Cicer Arietinum, PEG, Gibberellic Acid, Salicylic Acid, Salt Stress and Citric Acid.

\section{INTRODUCTION}

Seeds plays important role in world's diet, as it takes half of per capita energy intake all over the globe; it comprises about $90 \%$ of all cultivar, in plant physiology, seed biology is one of the most researched area [1]. The genetics and physiology research manifest the importance of hormones (abscisic acid and gibberellic acid) in regulation of dormancy and seed germination [2]. In plant growth hormones plays important role in seed germination, hormones like ABA, gibberellic acid, ethylene, IAA, cytokines and etc [3]. The radical initiation, elongation and development can be regulated by growth hormones, it is mainly affected by sun light and its intensity, water availability, aeration of soil, amount of carbohydrate efficiency and nutrients (macronutrients and micronutrients); the soil consist micro-organisms, mesofauna and macrofauna which can increase or decrease the rate of root growth as the sarietinum is 
important pulse crop grown and consumed as diet all over the world, it contains carbohydrate and protein; other than sulphur containing amino acid it has significant amount which can be complemented by adding cereals to the daily diety; it has good influence on some of the human disease like diabetes type 2, some cancer, digestive disease and CVD; it is an important pulse crop with diverse array of potential nutrition and health benefits [5].The utmost aim of Cicer arietinum propogation is to increase the production the genetic potential of cultivars or by removing the effect of drought, cold, disease and insect [6].

\section{MATERIALS AND METHODOLOGY}

\section{A. Chemicals/solutions}

1. $\mathrm{NaCl}$-The legume crop like chickpea is an important food in Turkey and it is vastly grown on low misture or saline for human consumption. To see the effect in effect in electric conductivities $(4.5,8.6$, 12.7 and $16.3 \mathrm{dS} / \mathrm{m}$ ) and in seed sizes (7, 8 and 9) on germination and in beginning seedling growth of 3 popular chickpea cultivars (AKN-97, Gokce and Uzunlu-99), the use of small seeds of chickpea was seems to reduce the production costs in saline soils [7]. In chickpea plant, $\mathrm{NaCl}$ induced reactive oxygen species generation and antioxydative reactions in the leaves investigated in concentration-dependent manners, the concentration of $\mathrm{NaCl}$ was assisted by a step rise in the $\mathrm{H}_{2} \mathrm{O}_{2}$ and $\mathrm{O}_{2}{ }^{-}$. In chickpea, $\mathrm{NaCl}$ does trigger the antioxidative response and concluded that the plant is a good source of natural antioxidants [8]. In my experiment $\mathrm{NaCl}$ solution is used to see if the chickpea can survive the stress.

2. Salicylic acid - The foliar application of salicylic acid concentration $10^{-4} \mathrm{~mol} / \mathrm{L}, 10^{-5} \mathrm{~mol} / \mathrm{L}$ and $10^{-6} \mathrm{~mol} / \mathrm{L}$ was used to increase the dry mass per plant, nodule dry mass and leghemoglobin content, the effective concentration was $10^{-5} \mathrm{~mol} / \mathrm{L}>10^{-6} \mathrm{~mol} / \mathrm{L}>10^{-4} \mathrm{~mol} / \mathrm{L}>$ control in chick pea seeds [9]. The hormone plays a vital role in induction of plant protection against a variety biotic and abiotic stress through physiological, morphological and biochemical mechanism, from the concentration of salicylic acid $1,1.5$ and $2 \mathrm{mM}$, the $1.5 \mathrm{mM}$ seems favorable to plant and protect against biotic and abiotic stress in chick pea plant [10]. The salicylic acid solution in my work is used to see the chickpea germination and growth.

3. Gibberellic acid - The seeds of Cicer arietinum soaked in four concentrated GA solutions $0,10^{-7}, 10^{-6}$ and $10^{-5}$ for 4,8 and 12 hours and then sown in pots; the number of pods per plant, yielding of seed and protein content stimulated by $82.69 \%, 5.44 \%$ and $54.32 \%$ respectively [11]. In low temperature stress chickpea is sensitive, mainly during germination and stand formation, to rescue chickpea seed from chilling stress by priming them with GA in combination with GA in combination with hydropriming in different concentrations, $\mathrm{GA}_{3}$ can be used for crop growth, maintaining high relative water content, good stand establishment and reducing electrolyte leakage [12].the GA solution in my experiment is used to see the chickpea seed germination and physiological growth.

4. Citric acid - Ameliorate the phytoextraction of $\mathrm{Cd}$ (cadmium) by the application of citric acid on hydroponic plants under controlled condition, the citric acid increases the $\mathrm{Cd}$ absorption and decreases the Cd stress it is beneficial for phytoextraction of $\mathrm{Cd}$ through hyper accumulation of Brassica napus [13]. In both chickpea and Lens culinaris (Lentils) has changed in saponin and composition as they were investigated after soaked in distilled water, sodium bicarbonate and citric acid solutions. Soaking does not modify the content of saponin or composition of chickpeas and lentils even so the $\mathrm{pH}$ of the soaking solution, overall decreasing of saponin content was found in lentils but not for chickpea [14]. The citric acid stress is given to the chick pea in my experiment to see if it's going to survive or not. 
5. PEG (polyethylene glycol) - The effect water shortage induced by different potential level $(0,-0.4$, 0.6 and -0.8 ) of PEG 6000 and $\mathrm{NaCl}$ treatment on chick pea cultivars, lines at germination and early growth stages by sampling them after $4^{\text {th }}$ and $8^{\text {th }}$ day of incubation, PEG is showing more successful in inhibition than $\mathrm{NaCl}$ at the MPa level tested, all the genotypes tested could be classified as tolerant, moderately tolerant and sensitive one. Some species like Canitez and ILC-3279 are tolerant to PEG but ILC-3279 was sensitive to $\mathrm{NaCl}$ treatment [15]. The seeds of chick pea (GG-1 and GJG-3) with seed coat, for seed priming with 6 treatments including $\mathrm{KNO}_{3}$ 200pm, PEG 6000 (-1.2MPa), Bavistin (2g/kg), neem oil (3\%), control in complete randomized design (CRD) with three replications, seeds will be soaked for 8 hrs for priming respectively air dried and put it on germination test by keeping them in between paper at $25^{\circ} \mathrm{C}$, at the end seeds with radical are counted as germinated [16]. In my work, chick pea seeds are treated with PEG solution to see the germination and seedling growth.

\section{B. Source of seeds and solutions:}

The seeds of Cicer arietinum are purchased from supermarket in Ahmedabad, Gujarat, India. The experiment is done at home and solutions (PEG, Salicylic acid, Citric acid, gibberellic acid $\mathrm{NaCl}$ and Mercuric chloride) are made in laboratory with the help of lemon, gibberellic acid, salicylic acid, $\mathrm{NaCl}$, PEG, glass ware (flask, beaker, pipette and measuring cylinder) and machines (water bath and weighing machine). Glass ware like peteridish, glass container to put the solution in it and whatman paper are provided from laboratory of Department of Botany, Bioinformatics and climate change impact management of Gujarat University, Ahmedabad, India 380009; during February and March 2021.

\section{Making of solutions and $\mathrm{pH}$}

The solutions made in lab for citric solution $30 \mathrm{ml}$ of citric juice with $220 \mathrm{ml}$ of distilled water, for $\mathrm{NaCl}$ solution $5.845 \mathrm{gm}$ of $\mathrm{NaCl}$ powder with 1 liter of distilled water, for PEG solution first to warm $500 \mathrm{ml}$ of distilled water with $2.5 \mathrm{ml}$ of PEG, for salicylic acid solution $500 \mathrm{ml}$ distilled water with $0.006 \mathrm{gm}$ of salicylic acid powder and for gibberellic acid solution $248 \mathrm{ml}$ of distilled water with $2.5 \mathrm{ml}$ of GA from stock solution. For sterilization of seeds $\mathrm{HgCl}_{2}$ is used and its solution is made with $100 \mathrm{ml}$ of distilled water with $0.052 \mathrm{gm}$ of mercuric chloride.

\section{TABLE NO.1- PH OF SOLUTIONS}

\begin{tabular}{|l|l|}
\hline Solutions & $\mathrm{pH}$ \\
\hline Citric acid & 3.96 \\
\hline $\mathrm{NaCl}$ & 7.44 \\
\hline Salicylic acid & 7.85 \\
\hline Gibberellic acid & 6.86 \\
\hline PEG & 7.84 \\
\hline Distilled water & 7.20 \\
\hline
\end{tabular}

The table no. 1 shows that citric acid solution is more acidic compare to other solution.

\section{Seed germination and seedling growth}

The seeds of chick pea were sterilized with mercuric chloride foe 3 minutes and washed with distilled water thoroughly to remove the traces of mercuric chloride, and then seeds air dried after that the seeds put in petridish which are $10 \mathrm{~cm}$ in diameter with whatman paper, they are $12.5 \mathrm{~cm}$ in diameter and with their respective solution. There are 6 petridishs one for each 5 solutions and distilled water and each petridish had 20 to 30 seeds of chickpea for 10 days. Next step for seedling growth is to transfer the germinated seeds in mud pot with soil and irrigate them with their respective solution and distilled water. 


\section{RESULT AND DISCUSSION}

\section{A. Total number of seeds and number of germinated seeds}

The total number of seeds Cicer arietinumare 105 and number of germinated seeds are 85, in which 28 germinated seeds of gibberellic acid solution, 26 germinated seeds of PEG solution and 30 germinated seeds of distilled water.

\section{B. Effect of solutions on the seeds}

The germination is seen only in PEG solution, gibberellic acid solution and distilled water but did not give result in $\mathrm{NaCl}$ solution, citric acid solution and salicylic acid solution.

\section{Result tables:}

TABLE NO.2: WEIGHT OF CICER ARIETINUM PLANT

\begin{tabular}{|c|c|c|c|c|}
\hline Days & Solutions & $\begin{array}{c}\text { Leaves } \\
\text { (gm) }\end{array}$ & $\begin{array}{c}\text { Roots } \\
\text { (gm) }\end{array}$ & $\begin{array}{c}\text { Shoots } \\
\text { (gm) }\end{array}$ \\
\hline After & PEG & 0.087 & 0.078 & 0.153 \\
5 days & GA & 0.069 & 0.081 & 0.209 \\
& TW & 0.142 & 0.069 & 0.281 \\
\hline After & PEG & 0.123 & 0.080 & 0.442 \\
10 & GA & 0.159 & 0.094 & 0.350 \\
days & TW & 0.333 & 0.095 & 0.557 \\
\hline After & PEG & 0.295 & 0.084 & 0.524 \\
15 & GA & 0.244 & 0.130 & 0.513 \\
days & TW & 0.364 & 0.096 & 0.649 \\
\hline After & PEG & 0.274 & 0.048 & 0.514 \\
20 & GA & 0.172 & 0.030 & 0.475 \\
days & TW & 0.202 & 0.047 & 0.417 \\
\hline
\end{tabular}

The table no. 2 shows the highest result in after 15 days of plant's weight than after 20 days and in after 15 days, GA shows good result in root and tap water gives good result in leaves and shoots. (Abbreviatio: PEG- Polyethylene glycol, GA- gibberelic acid and TW- tap water)

TABLE NO.3: LENGTH OF ROOTS AND SHOOTS (CICER ARIETINUM PLANTS)

\begin{tabular}{|c|c|c|c|}
\hline Days & Solutions & $\begin{array}{c}\text { Roots } \\
\text { (cm) }\end{array}$ & $\begin{array}{c}\text { Shoots } \\
\text { (cm) }\end{array}$ \\
\hline After 5 & PEG & 0.8 & 9.2 \\
days & GA & 1.8 & 10.2 \\
& TW & 2.0 & 12.6 \\
\hline After 10 & PEG & 3.3 & 10.2 \\
days & GA & 4.3 & 23.7 \\
& TW & 5.5 & 28.4 \\
\hline After 15 & PEG & 6.7 & 32.3 \\
days & GA & 4.5 & 29.0 \\
& TW & 3.7 & 32.5 \\
\hline After 20 & PEG & 3.7 & 35.2 \\
days & GA & 4.5 & 36.5 \\
& TW & 2.5 & 30.5 \\
\hline
\end{tabular}

Table no.2 shows the after 15 days plant shows good height than after 20 days; in after 15 days the root of PEG is the highest and shoot of tap water is the highest compare to other.

TABLE NO.3: LENGTH AND WIDTH OF PLANT'S LEAF AND ITS LEAFLET (CICER ARIETINUM)

\begin{tabular}{|c|c|c|c|c|c|}
\hline Days & Solutions & \multicolumn{2}{|c|}{ Length (cm) } & \multicolumn{2}{c|}{ Width (cm) } \\
\cline { 3 - 6 } & & Leaf & Leaflet & Leaf & Leaflet \\
\hline After & PEG & 1.5 & 0.4 & 0.8 & 0.3 \\
5 & GA & 1.0 & 0.4 & 0.8 & 0.4 \\
days & TW & 0.6 & 0.6 & 1.1 & 0.4 \\
\hline After & PEG & 3.8 & 0.8 & 1.5 & 0.5 \\
10 & GA & 4.4 & 0.8 & 1.5 & 0.7 \\
days & TW & 5.3 & 1.0 & 2.0 & 0.8 \\
\hline After & PEG & 4.6 & 0.8 & 1.6 & 0.6 \\
15 & GA & 4.5 & 0.8 & 1.6 & 0.7 \\
days & TW & 5.4 & 1.0 & 2.0 & 0.8 \\
\hline After & PEG & 4.3 & 0.9 & 1.5 & 0.7 \\
20 & GA & 4.0 & 0.5 & 1.1 & 0.5 \\
days & TW & 4.5 & 0.9 & 1.6 & 0.7 \\
\hline
\end{tabular}

The table no. 3 shows the after 15 days leaf and leaflet is wider than after 20 days; in after 15 days tap water leaf and leaflet is giving the good growth than other. 
Graph of the result tables (table no. 2, 3 and 4):

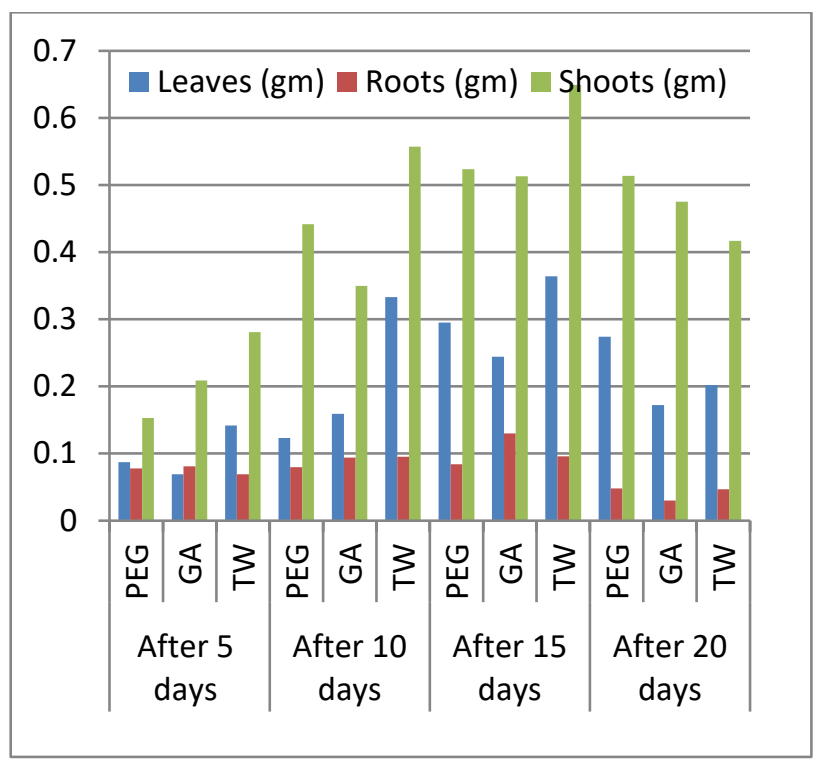

Figure 1 : weight of Cicer arietinum plants (leaves, roots and shoots)

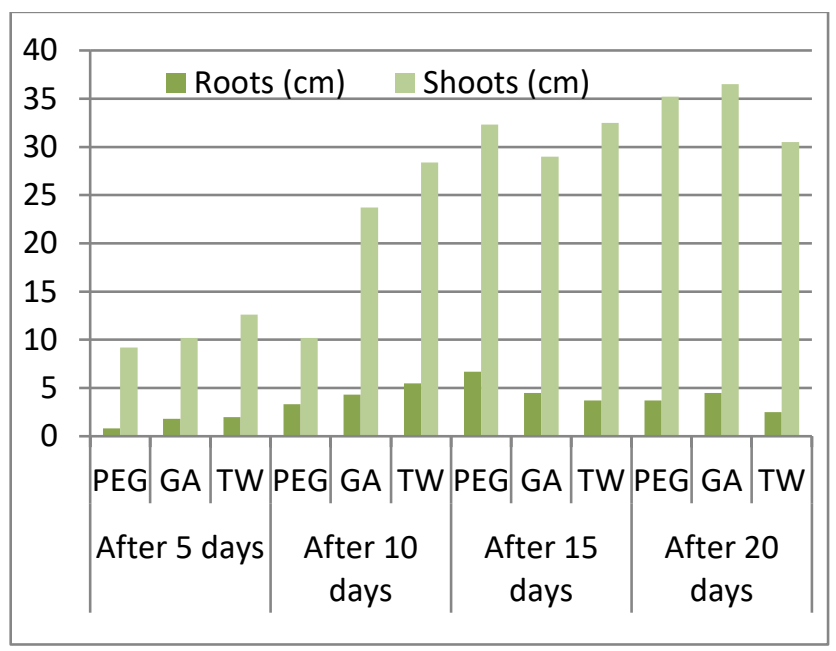

Figure 2 : length of Cicer arietinum plant (roots and shoots).

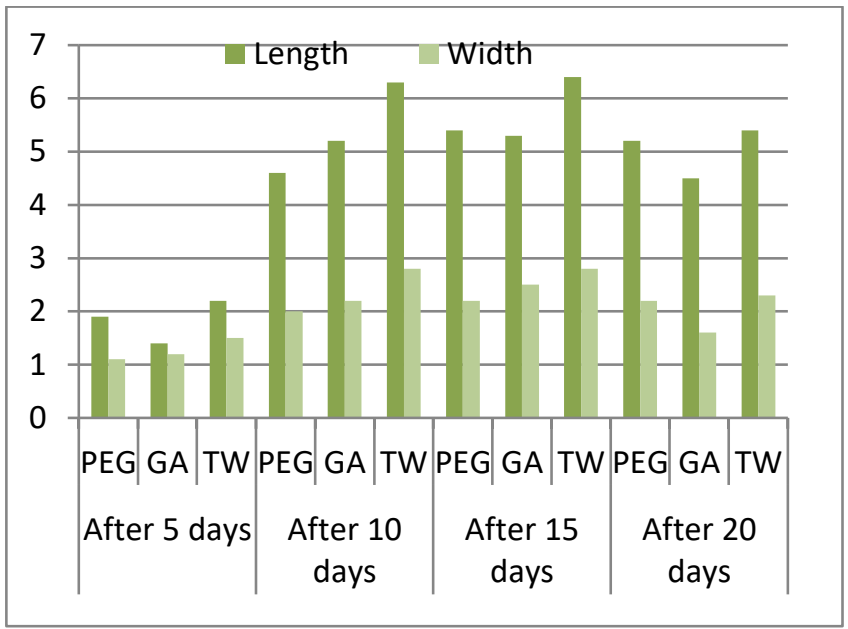

Figure 3 : length and width of Cicer arietinum leaves.

\section{CONCLUSION}

It turns out that the most of Cicer arietinum seeds germinated in PEG solution, gibberellic acid solution and control (distilled water). In salicylic solution, $\mathrm{NaCl}$ solution and citric solution doesn't germinate and get blackish in colour, busted and contaminated. In pot PEG and tap water gives more result than gibberelic acid solution.

\section{REFERENCES}

[1]. Bewley, J. D. (1997). Seed germination and dormancy. The plant cell, 9(7), 1055.

[2]. Koornneef, M., Bentsink, L., \& Hilhorst, H. (2002). Seed dormancy and germination. Current opinion in plant biology, 5(1), 33-36.

[3]. Miransari, M., \& Smith, D. L. (2014). Plant hormones and seed germination. Environmental and experimental botany, 99, 110-121.

[4]. Lynch, J., Marschner, P., \&Rengel, Z. (2012). Effect of internal and external factors on root growth and development. In Marschner's mineral nutrition of higher plants (pp. 331346). Academic Press.

[5]. Jukanti, A. K., Gaur, P. M., Gowda, C. L. L., \& Chibbar, R. N. (2012). Nutritional quality and health benefits of chickpea (Cicer arietinum L.): 
a review. British Journal of Nutrition, 108(S1), S11-S26.

[6]. Singh, K. B. (1997). Chickpea (Cicer arietinum L.). Field crops research, 53(1-3), 161-170.

[7]. Kaya, M., Kaya, G., Kaya, M. D., Atak, M., Saglam, S., Khawar, K. M., \& Ciftci, C. Y. (2008). Interaction between seed size and $\mathrm{NaCl}$ on germination and early seedling growth of some Turkish cultivars of chickpea (Cicer arietinum L.). Journal of Zhejiang University Science B, 9(5), 371-377.

[8]. Mishra, M., Mishra, P. K., Kumar, U., \& Prakash, V. (2009). NaCl phytotoxicity induces oxidative stress and response of antioxidant systems in Cicer arietinum L. cv. Abrodhi. Botany Research International, 2(2), 74-82.

[9]. Hayat, Q., Hayat, S., Alyemeni, M. N., \& Ahmad, A. (2012). Salicylic acid mediated changes in growth, photosynthesis, nitrogen metabolism and antioxidant defense system in Cicer arietinum L. Plant, Soil and Environment, 58(9), 417-423.

[10]. War, A. R., Paulraj, M. G., War, M. Y., \& Ignacimuthu, S. (2011). Role of salicylic acid in induction of plant defense system in chickpea (Cicer arietinum L.). Plant signaling \& behavior, 6(11), 1787-1792.

[11]. Mazid, M. (2014). Seed priming application of gibberellic acid on growth, biochemical, yield attributes and protein status of chickpea (Cicer arietinum L. cv. DCP 92-3). International Journal of Genetic Engineering and Biotechnology, 5(1), 17-22.

[12]. Aziz, T., \& Pekşen, E. (2020). Seed priming with gibberellic acid rescues chickpea (Cicer arietinum L.) from chilling stress. Acta Physiologiae Plantarum, 42(8), 1-10.

[13]. Ehsan, S., Ali, S., Noureen, S., Mahmood, K., Farid, M., Ishaque, W., ... \& Rizwan, M. (2014). Citric acid assisted phytoremediation of cadmium by Brassica napus L. Ecotoxicology and environmental safety, 106, 164-172.
[14]. Ruiz, R. G., Price, K. R., Arthur, A. E., Rose, M. E., Rhodes, M. J., \& Fenwick, R. G. (1996). Effect of soaking and cooking on the saponin content and composition of chickpeas (Cicer arietinum) and lentils (Lens culinaris). Journal of Agricultural and Food Chemistry, 44(6), 1526-1530.

[15]. KALEFETOĞLU, T., TURAN, Ö., \& EKMEKÇİ, Y. (2009). Effects of Water Deficit Induced by PEG and $\mathrm{NaCl}$ onChickpea (Cicer arietinum L.) Cultivars and Lines at Early Seedling Stages. Gazi University Journal of Science, 22(1), 5-14.

[16]. Patil, K., Ravat Anilkumar, L., Trivedi, V., Hirpara, A., \& Sasidharan, N. (2018). Effect of seed priming treatment in chickpea (Cicer arietinum L.). IJCS, 6(4), 1064-1069.

\section{Cite this article as :}

Sneha Pandey, Kalpa Oza, Bharat Maitreya, "Effect of Different Solutions on Seed Germination and Physiological Changes in Cicer arietinum", International Journal of Scientific Research in Science and Technology (IJSRST), Online ISSN : 2395-602X, Print ISSN : 2395-6011, Volume 8 Issue 2, pp. 295-300, March-April 2021. Available at doi : https://doi.org/10.32628/IJSRST218246 Journal URL : https://ijsrst.com/IJSRST218246 